\title{
Diet of the Clupeid Fish Platanichthys platana (Regan, 1917) in Two Different Brazilian Coastal Lagoons
}

\author{
Talita Aguiaro ${ }^{1 *}$, Christina Wyss Castelo Branco ${ }^{2}$, José Roberto Verani ${ }^{1}$ and Érica \\ Pellegrini Caramaschi ${ }^{3}$ \\ ${ }^{1}$ Department of Hydrobiology; UFSCar; São Carlos - SP - Brazil. ${ }^{2}$ Department of Natural Sciences; UNIRIO; \\ Rio de Janeiro - RJ - Brazil. ${ }^{3}$ Department of Ecology; UFRJ; Rua Voluntários da Pátria, 107; CEP 22270-000; \\ Rio de Janeiro - RJ - Brazil
}

\begin{abstract}
Platanichthys platana is considered a constant species in both Cabiunas and Imboassica lagoons that are characterised by different marine and freshwater inputs, and anthropogenic influences. The stomach content analysis of P. platana captured between July 1991 and July 1993 revealed filamentous algae, detritus, eggs of benthic invertebrates, larvae of chironomids and bivalves as the main food sources in Imboassica lagoon. Smallsized cladocerans, copepods and shrimp larvae were the prevailing items in Cabiunas lagoon. Seasonal food variations were noted for the fishes of Imboassica lagoon. Diet differences were highlighted within specimens lesser than $40 \mathrm{~mm}$ standard length in Imboassica lagoon, and were related to the increase of marine influence due to artificial sand barrier openings. Dissimilarities among size classes in relation to invertebrate larvae consumption were observed in fishes from Cabiúnas lagoon.
\end{abstract}

Key words: Brazil, coastal lagoons, food items, Platanichthys platana

\section{INTRODUCTION}

The subtropical coastline of the Southeast Brazil has a series of shallow mesotrophic to hypereutrophic lagoons that differ in dimensions, marine influence and are included either in pristine regions or are surrounded by urban areas. These ecosystems are used for many purposes such as recreational and fishery activities, and also to waste water disposal. Aquatic communities and limnological features of the coastal lagoons Imboassica and Cabiúnas, located in the Rio de Janeiro State northern coast, have been intensively studied since 1992 (Aguiaro and Caramaschi, 1995, 1998; Branco, 1998; Esteves, 1998). The results showed systems characterised by a high dynamic physical and biological environment that change continuously. Most of these changes are related to the input of fresh and marine water which concurrent with the anthropogenic impacts constitute the most important factor controlling the aquatic communities.

Fish assemblage of Imboassica and Cabiúnas lagoons presents both freshwater and marine species (Aguiaro, 1994), and as other aquatic communities is highly influenced by the intensity of seawater inputs. The descriptions of fish trophic structure have revealed the dominance of detritivorous and microphagous guilds (Aguiaro and Caramaschi, 1998; Aguiaro, 1999) and in

\footnotetext{
* Author for correspondence
} 
consequence, the importance of food sources such as detritus and invertebrates to fish community. The present work is part of a comprehensive study on the diet of most frequent and abundant species of fish in Brazilian coastal lagoons. An important question concerns the feeding habits of fishes during all the year and in different environmental conditions. Another question regards the resulting effect of fish predation on other aquatic communities. The clupeid Platanichthys platana (Regan, 1917), a constant species in both Cabiúnas and Imboassica lagoons, is commonly found in brackish water and is recognised as the smallest sardine of Brazilian coast. It was included in the microphagous guild and due to its high abundance in Imboassica lagoon, $P$. platana probably plays an important role on the energy flow in this latter environment.

\section{MATERIALS AND METHODS}

\section{Study Site}

Imboassica and Cabiúnas lagoons are situated in the south-eastern coast of Brazil $\left(22^{\circ} 24^{\prime} \mathrm{S}\right.$ and $\left.41^{\circ} 42^{\prime} \mathrm{W}\right)$. Both are separated from the sea by a sand barrier about $50 \mathrm{~m}$ wide (Aguiaro and Caramaschi, 1995). Imboassica lagoon has suffered an increasing anthropogenic influence due to input of raw sewage from residences located at its margins, and to the artificial openings of its sand barrier. This latter impact is frequent during the rainy season, when inundation of residential areas occurs, and it causes the drainage of almost all the water of the lagoon into the sea, turning the oligohaline environment into an euhaline one. Cabiúnas lagoon is located in the recently created Jurubatiba National Park, which comprehends an area of natural "restinga" vegetation. The lagoon water has brown-colour due to humic acids carried from the "restinga" soils, and its margins are dominated by several species of aquatic macrophytes. The environment is considered freshwater since openings of the sand barrier seldom happen and they are caused by natural events such as intense rains in the drainage basin.

\section{Sampling}

Individuals of $P$. platana were caught with beachseines between July 1991 and July 1993 and the stomach content analysis was proceeded using Sedgewick-Rafter counting chambers with 1-ml capacity. Food items analysis was done according to occurrence, numeric and volumetric methods as described by Hyslop (1980) and Branco et al. (1997). The index of relative importance (IRI) was also calculated (Pinkas, 1971). The fishes were grouped, based on standard length, in size classes with intervals of $10 \mathrm{~mm}$. Seasonal and ontogenetic differences in the diets were detected using chisquared test $(\mathrm{p}<0.05)$.

\section{RESULTS AND DISCUSSION}

Stomach contents $(\mathrm{n}=47)$ of $P$. platana collected in Imboassica lagoon presented 57 food items whilst 24 items were found in the contents of individuals $(n=13)$ captured in Cabiúnas lagoon. The heterogeneity of items in Imboassica lagoon could be explained by the highest number of fishes collected in this ecosystem and by a periodic influence of environment alterations on the common foraging communities. Changes in the occurrence and in the population abundance of planktonic, benthic and periphythic organisms due to passive transport, osmotic stress and food availability were some of the detected consequences of the frequent artificial sand barrier openings (Branco, 1998; Fernandes, 1998; Gonçalves et al., 1998). Despite the existence of 19 food items common to both the lagoons, the frequency of occurrence, numeric and volumetric percents and feeding index (IRI) showed distinct diets (Table 1). The IRI index, which used occurrence, numeric and volumetric data, indicated that the most consumed items in Imboassica lagoon were the filamentous algae Spirogyra sp., detritus, eggs of benthic invertebrates, larvae of bivalves and chironomids.

The numeric and volumetric percents showed similar results in different order. On the other hand, the IRI, in accordance with numeric and volumetric percents, revealed calanoid copepods, shrimp larvae, cladocerans, eggs of copepods and other invertebrates as the main food items in the diet of P. platana of Cabiúnas lagoon (Table 1). Our results characterised $P$. platana as a particulate feeder (sensu Lazarro, 1987), which exhibited different feeding habits when the two lagoons were compared. 
Table 1 - Frequency of occurrence $(\% \mathrm{~F})$, numeric $(\% \mathrm{~N})$ and volumetric $(\% \mathrm{~V})$ percentuals of food items, index of relative importance (IRI) and average number of each item consumed by Platanichthys platanaiollected in Imboassica (IMB) and Cabiúnas (CAB) lagoons (Rio de Janeiro, Brazil).

\begin{tabular}{|c|c|c|c|c|c|c|c|c|c|c|c|}
\hline & \multirow[b]{2}{*}{ ITEMS } & \multicolumn{2}{|c|}{$\% \mathrm{~F}$} & \multicolumn{2}{|c|}{$\% \mathrm{~N}$} & \multicolumn{2}{|c|}{$\% \mathrm{~V}$} & \multicolumn{2}{|c|}{ IRI } & \multicolumn{2}{|c|}{ Average number } \\
\hline & & $\mathrm{CAB}$ & IMB & $\mathrm{CAB}$ & IMB & CAB & IMB & CAB & IMB & $\mathrm{CAB}$ & IMB \\
\hline & Bacillariophyceae & - & 19.15 & - & 1.06 & - & 0.03 & - & 20.99 & - & 18.78 \\
\hline & Chlorophyceae & & & & & & & & & & \\
\hline & Ulothrix sp. & - & 4.26 & - & 0.12 & - & 0.04 & - & 0.66 & - & 9.50 \\
\hline & Cyanophyceae & - & 10.64 & - & 0.25 & - & 0.0001 & - & 2.62 & - & 7.80 \\
\hline & Lyngbia sp. & - & 6.38 & - & 0.38 & - & 0.11 & - & 3.12 & - & 20.00 \\
\hline $\mathbf{A}$ & Merismopedia sp. & - & 10.64 & - & 0.06 & - & 0.01 & - & 0.75 & - & 1.80 \\
\hline $\mathbf{L}$ & Microcystis sp. & - & 10.64 & - & 0.57 & - & 0.34 & - & 9.69 & - & 18.20 \\
\hline $\mathbf{G}$ & Oscillatoria sp. & - & 2.13 & - & 0.03 & - & 0.01 & - & 0.07 & - & 4.00 \\
\hline \multicolumn{12}{|c|}{ A Zygnemaphycea } \\
\hline \multirow[t]{8}{*}{$\mathbf{E}$} & Closterium sp. & - & 6.38 & - & 0.04 & - & 0.003 & - & 0.30 & - & 2.33 \\
\hline & Cosmarium sp. & - & 6.38 & - & 0.16 & - & 0.005 & - & 1.08 & - & 8.67 \\
\hline & Desmidium sp. & - & 6.38 & - & 0.14 & - & 0.04 & - & 1.15 & - & 7.33 \\
\hline & Mougeotia sp. & 7.69 & 2.13 & 0.07 & 0.73 & 0.003 & 0.22 & 0.54 & 2.01 & 3.00 & 116.00 \\
\hline & Spirogyra sp. & - & 25.53 & - & 66.62 & - & 19.59 & - & 2201.24 & - & 881.00 \\
\hline & Chara sp. & - & 2.13 & - & 7.13 & - & 2.10 & - & 19.64 & - & 1132.00 \\
\hline & Protozoa & & & & & & & & & & \\
\hline & Testacea & - & 2.13 & - & 0.01 & - & 0.0002 & - & 0.01 & - & 1.00 \\
\hline $\mathbf{Z}$ & Rotifera & 30.77 & 21.28 & 0.09 & 0.23 & 0.002 & 0.03 & 2.79 & 5.54 & 1.00 & 3.70 \\
\hline $\mathbf{O}$ & Crustacea & & & & & & & & & & \\
\hline $\mathbf{O}$ & Cladocera & 69.23 & 12.77 & 7.24 & 0.07 & 3.58 & 0.20 & 748.69 & 3.49 & 36.11 & 1.83 \\
\hline $\mathbf{P}$ & Cladocera Macrotricidae & 7.69 & - & 0.04 & - & 0.02 & - & 0.51 & - & 2.00 & - \\
\hline $\mathbf{L}$ & Cladocera Chidoridae & - & 17.22 & - & 0.23 & - & 0.67 & - & 15.22 & - & 4.50 \\
\hline $\mathbf{L}$ & Diaphanosoma sp. & 30.77 & 4.26 & 2.23 & 0.01 & 2.42 & 0.08 & 143.05 & 0.40 & 25.00 & 1.00 \\
\hline $\mathbf{A}$ & Bosminopsis sp. & 53.85 & 2.13 & 9.91 & 0.02 & 1.18 & 0.01 & 596.76 & 0.07 & 63.57 & 3.00 \\
\hline $\mathbf{N}$ & Moina sp. & 23.08 & 6.38 & 1.22 & 0.05 & 0.48 & 0.12 & 39.44 & 1.08 & 18.33 & 2.67 \\
\hline $\mathbf{K}$ & Ceriodaphnia sp. & 7.69 & - & 0.09 & - & 0.01 & - & 0.79 & - & 4.00 & - \\
\hline $\mathbf{T}$ & Copepoda & - & 12.77 & - & 0.23 & - & 2.40 & - & 33.56 & - & 6.00 \\
\hline $\mathbf{O}$ & Copepoda Calanoida & 84.62 & 19.15 & 33.84 & 0.28 & 60.27 & 2.94 & 7962.58 & 61.53 & 138.18 & 4.89 \\
\hline $\mathbf{N}$ & Copepoda Ciclopoida & 7.69 & 10.64 & 0.04 & 0.47 & 0.05 & 3.29 & 0.75 & 39.98 & 2.00 & 14.80 \\
\hline & Copepoda Harpacticoida & 30.77 & 17.02 & 0.22 & 0.16 & 0.18 & 0.74 & 12.27 & 15.30 & 2.50 & 3.13 \\
\hline & nauplii & - & 21.28 & - & 3.19 & - & 0.75 & - & 83.97 & - & 50.70 \\
\hline & L.Chaoboridae & 23.08 & 10.64 & 0.40 & 0.03 & 0.79 & 0.37 & 27.55 & 4.28 & 6.00 & 1.00 \\
\hline $\mathbf{L}$ & L.Chironomidae & 7.69 & 27.66 & 0.02 & 0.55 & 0.03 & 4.89 & 0.43 & 150.68 & 1.00 & 6.77 \\
\hline $\mathbf{A}$ & L. Cirripedia & - & 29.79 & - & 0.60 & - & 1.76 & - & 70.28 & - & 6.79 \\
\hline $\mathbf{R}$ & L. Polychaeta & - & 6.38 & - & 0.04 & - & 0.13 & - & 1.11 & - & 2.33 \\
\hline $\mathbf{V}$ & L. Decapoda & 69.23 & 4.26 & 13.85 & 0.03 & 27.40 & 0.30 & 2855.64 & 1.37 & 69.11 & 2.00 \\
\hline $\mathbf{A}$ & L. Bivalvia & - & 25.53 & - & 2.36 & - & 4.16 & - & 166.36 & - & 31.17 \\
\hline $\mathbf{E}$ & L. Gastropoda & 23.08 & 12.77 & 0.96 & 0.54 & 0.38 & 1.28 & 30.83 & 23.20 & 14.33 & 14.33 \\
\hline & L. Coleoptera & - & 2.13 & - & 0.01 & - & 0.06 & - & 0.13 & - & 1.00 \\
\hline & Peritricha & - & 2.13 & - & 0.32 & - & 0.01 & - & 0.69 & - & 50.00 \\
\hline & Nematoda & 15.38 & 8.51 & 0.07 & 0.04 & 0.01 & 0.04 & 1.23 & 0.70 & 1.50 & 1.50 \\
\hline $\mathbf{I}$ & Mollusca & & & & & & & & & & \\
\hline $\mathbf{N}$ & Gastropoda (Heleobia) & - & 6.38 & - & 0.37 & - & 8.75 & - & 58.21 & - & 19.67 \\
\hline $\mathbf{V}$ & Polychaeta & - & 2.13 & - & 0.01 & - & 0.07 & - & 0.17 & - & 1.00 \\
\hline $\mathbf{E}$ & Oligochaeta & - & 2.13 & - & 0.02 & - & 0.01 & - & 0.06 & - & 3.00 \\
\hline $\mathbf{R}$ & Crustacea & & & & & & & & & & \\
\hline $\mathbf{T}$ & Ostracoda & - & 10.64 & - & 0.11 & - & 0.04 & - & 1.54 & - & 3.40 \\
\hline & Amphipoda & - & 4.26 & - & 0.04 & - & 1.04 & - & 4.60 & - & 3.50 \\
\hline $\begin{array}{l}\mathbf{E} \\
\mathbf{P}\end{array}$ & Tanaidacea & - & 2.13 & - & 0.02 & - & 0.22 & - & 0.51 & - & 3.00 \\
\hline B & Isopoda & - & 2.13 & - & 0.01 & - & 0.22 & - & 0.49 & - & 1.00 \\
\hline $\mathbf{R}$ & Isopoda Cymothoidae & - & 6.38 & - & 0.04 & - & 1.56 & - & 10.22 & - & 2.33 \\
\hline A & Emerita sp. & - & 2.13 & - & 0.01 & - & 0.04 & - & 0.09 & - & 1.00 \\
\hline $\mathbf{T}$ & Insecta & - & & - & & - & & - & & - & \\
\hline $\mathbf{E}$ & Diptera pupae & - & 21.28 & - & 0.19 & - & 3.34 & - & 75.01 & - & 3.00 \\
\hline $\mathbf{S}$ & Diptera & - & 2.13 & - & 0.01 & - & 0.10 & - & 0.23 & - & 1.00 \\
\hline & Hymenoptera & - & 4.26 & - & 0.01 & - & 0.15 & - & 0.68 & - & 1.00 \\
\hline & Ephemeroptera nimph & 7.69 & - & 0.04 & - & 0.05 & - & 0.72 & - & 2.00 & - \\
\hline D & Detritus & 7.69 & 14.89 & 0.33 & 2.43 & 0.33 & 14.27 & 5.11 & 248.69 & 15.00 & 55.00 \\
\hline $\mathbf{I}$ & Bristles & - & 10.64 & - & 0.54 & - & 0.003 & - & 5.80 & - & 17.20 \\
\hline $\mathbf{V}$ & Lepidoptera scales & - & 4.26 & - & 0.07 & - & 0.001 & - & 0.30 & - & 5.50 \\
\hline $\mathbf{E}$ & Fish scales & - & 19.15 & - & 0.14 & - & 0.82 & - & 18.27 & - & 2.44 \\
\hline $\mathbf{R}$ & Cladocera ephippium & 7.69 & - & 0.18 & - & 0.02 & - & 1.51 & - & 8.00 & - \\
\hline $\mathbf{S}$ & Copepoda spermathophore & 38.46 & - & 2.43 & - & 0.60 & - & 116.41 & - & 21.80 & - \\
\hline $\mathbf{E}$ & Sand grains & 15.38 & 42.55 & 0.09 & 1.32 & 0.004 & 0.31 & 1.42 & 69.56 & 2.00 & 10.50 \\
\hline $\mathbf{I}$ & Copepoda eggs & 53.85 & 10.64 & 10.42 & 0.09 & 0.10 & 0.01 & 566.55 & 1.06 & 66.86 & 3.00 \\
\hline $\mathbf{T}$ & Invertebrates eggs & 46.15 & 38.30 & 14.27 & 4.07 & 0.14 & 0.24 & 665.12 & 165.08 & 106.83 & 35.89 \\
\hline $\mathbf{E}$ & Vegetation debris & - & 10.64 & - & 0.20 & - & 1.18 & - & 14.65 & - & 6.35 \\
\hline M & Insects remains & - & 10.64 & - & 0.11 & - & 0.67 & - & 8.31 & - & 3.60 \\
\hline $\mathbf{S}$ & Unidentified items & 53.85 & 51.06 & 1.96 & 3.44 & 1.94 & 20.25 & 209.86 & 1209.77 & 12.57 & 22.76 \\
\hline
\end{tabular}


This fact was according to the theory of optimal foraging, in which the most frequently eaten prey are the most abundant, largest and most easily captured organisms (Kornijów, 1997).

The frequent contacts with the sea, through sand barrier openings, impair the reproduction of freshwater shrimps and influence the zooplankton community in Imboassica lagoon. Whereas rotifers of small size and larvae of benthic organisms were common in this lagoon, calanoid copepods and cladocerans together with rotifers were the prevailing zooplankters in Cabiúnas lagoon (Branco, 1998). The lower availability of larger zooplankters in Imboassica lagoon could also help to explain the higher number of food items and the considerable presence of items such as Spirogyra sp., detritus and also benthic invertebrates in the $P$. platana diet. Increases in biomass of filamentous algae, such as Spirogyra sp., are frequently detected in Imboassica lagoon and they have been connected to nutrient input from raw sewage drainage (Fernandes, 1998; Melo and Suzuki, 1998). In accordance to many authors that found detritus and plankton as the main food items captured by clupeids (CastilloRivera et al., 1996), our data showed the importance of the former in Imboassica lagoon and the prevailing of the latter in Cabiúnas lagoon. Seasonal differences were observed within the diets of fishes from Imboassica lagoon (Fig.1). The seasonal changes were related to the increase of marine influence due to the artificial sand barrier openings. During these events, benthic and limnetic organisms are carried out from the lagoon into the sea, and in conformity with the sea tide, there is a passive entrance of marine organisms such as algae, invertebrate and fish larvae and active entrance of adult fish. According to water conditions, the marine species can either perish or live during some weeks in the lagoon, along with some euhaline ones.

The population recovery of freshwater organisms is either fast or slow and conditioned on limnological features. The sand barrier openings contributed to enrich the diet of $P$. platana with Bivalve and Cirripedia larvae besides Amphipoda. Significant qualitative and quantitative seasonal variations among diets of $P$. platana from Cabiúnas lagoon were detected and attributed to a great shrimp larvae consumption in April (Fig. 2). Shrimp larvae of Palaemon pandaliformis live among the underwater vegetation along the shoreline of Cabiúnas lagoon (Albertoni, 1998) and were mainly consumed by larger individuals. Since the larvae are not produced all the year, changes in the availability of this food resource can be expected.

Dissimilarities among diets of fishes with distinct size classes were highlighted in Imboassica lagoon. Fishes with standard length lesser than 40 $\mathrm{mm}$, ingested smaller sized food items when compared with the individuals placed in the higher size classes, which in turn consumed more filamentous algae, benthic invertebrate and detritus (Fig. 3).This picture suggests unequal diet features between small and large specimens, including feeding behaviour and function in the trophic web. Ontogenetic changes are observed in a great number of fish species and are probably accounted for morphological and maturational changes. Furthermore, the selection may reflect the general rule that preys size is positively correlated with predator size (Zander and Berg, 1984).

The small number of individuals captured in Cabiúnas lagoon restricted the interpretation of the results and conclusive statements about seasonal and ontogenetic variations in this habitat. The diet analysis of the three size classes of $P$. platana of Cabiúnas lagoon showed the presence of cladocerans, copepods and shrimp larvae (Fig. 4). Conversely, there was a contrast among the classes in relation to the mean number of Chironomidae, Chaoboridae and Palaemonidae larvae consumption. These larvae were most preyed by larger individuals and, consequently, the important items according to IRI were often found in the stomachs of the larger specimens. The diet of $P$. platana in Cabiúnas lagoon suggested a tendency of direct impact on the large components of the zooplankton community and on the insect and shrimp larvae standing crop as formerly verified for other fishes both in tropical (Branco et al., 1997) and temperate regions (Kornijów, 1997).

Studies dealing with the diet of native fishes have given important clues about relations among different levels of the trophic web in aquatic ecosystems. According to our results, P. platana showed capacity to obtain resources from several trophic levels and under both freshwater and euhaline conditions. Further, individuals of 
different size classes in Imboassica and Cabiúnas lagoons could play an important role in the control of zooplankton, invertebrate larvae and even filamentous algae.

However, only after a better understanding of the mechanisms of such regulation, by way of experimental studies dealing with selective predation of $P$. platana, this application could be effectively suggested.

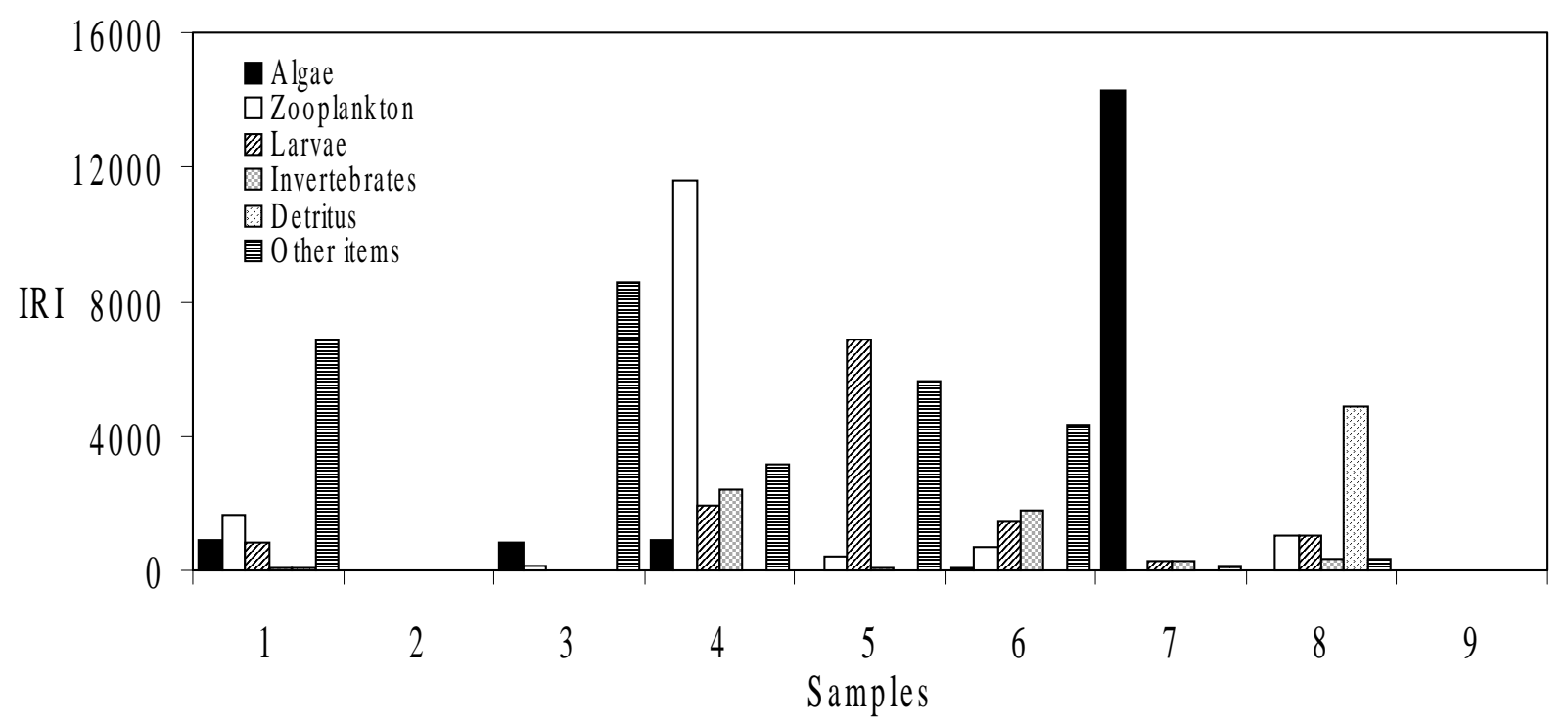

Figure 1 - Distribution of total values of index of relative importance (IRI) calculated for each food category through quarterly samples, for individuals $(\mathrm{n}=47)$ of Platanichthys platana collected in Imboassica lagoon (Rio de Janeiro, Brazil).

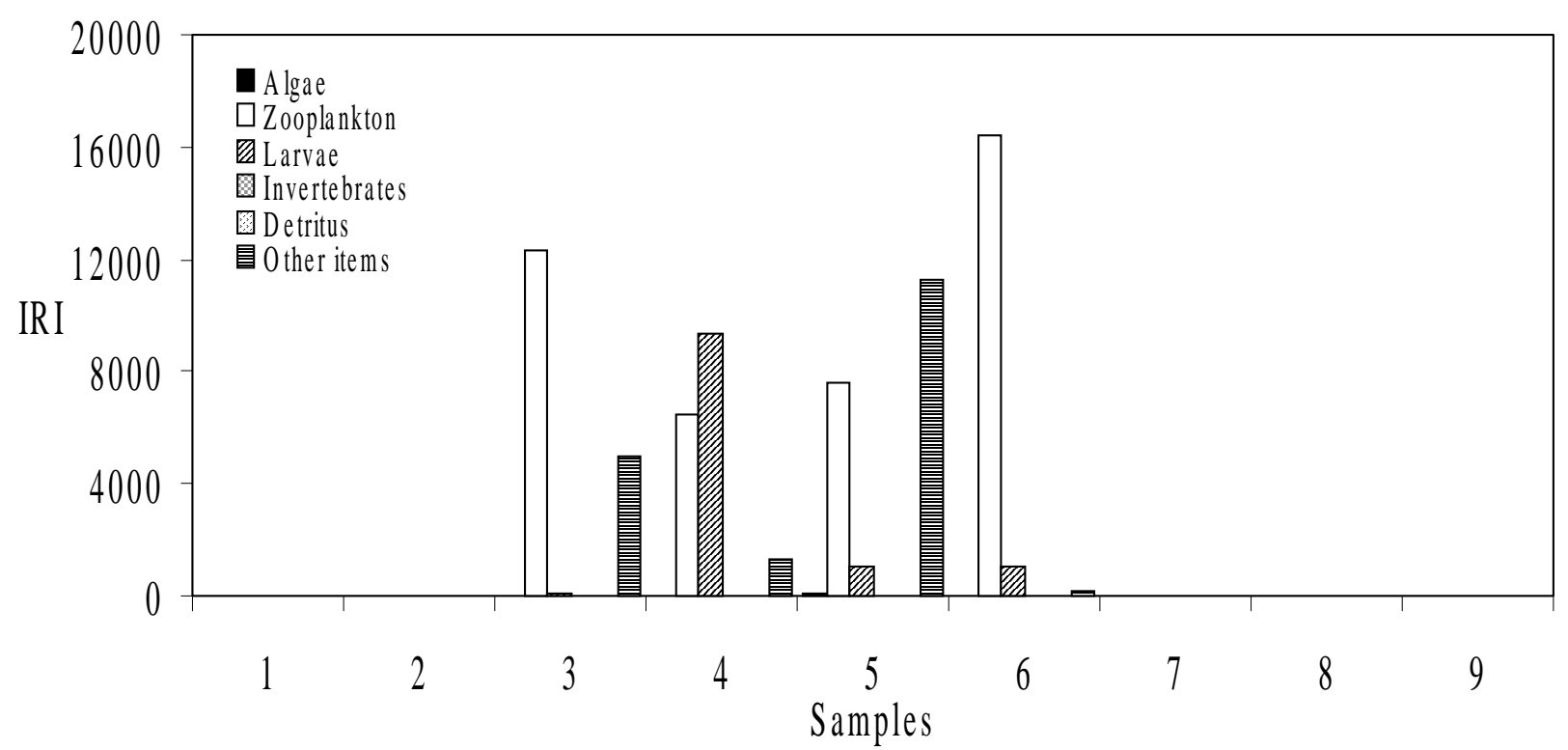

Figure 2 - Distribution of total values of index of relative importance (IRI) calculated for each food category through quarterly samples, for individuals $(\mathrm{n}=13)$ of Platanichthys platana collected in Cabiúnas lagoon (Rio de Janeiro, Brazil). 

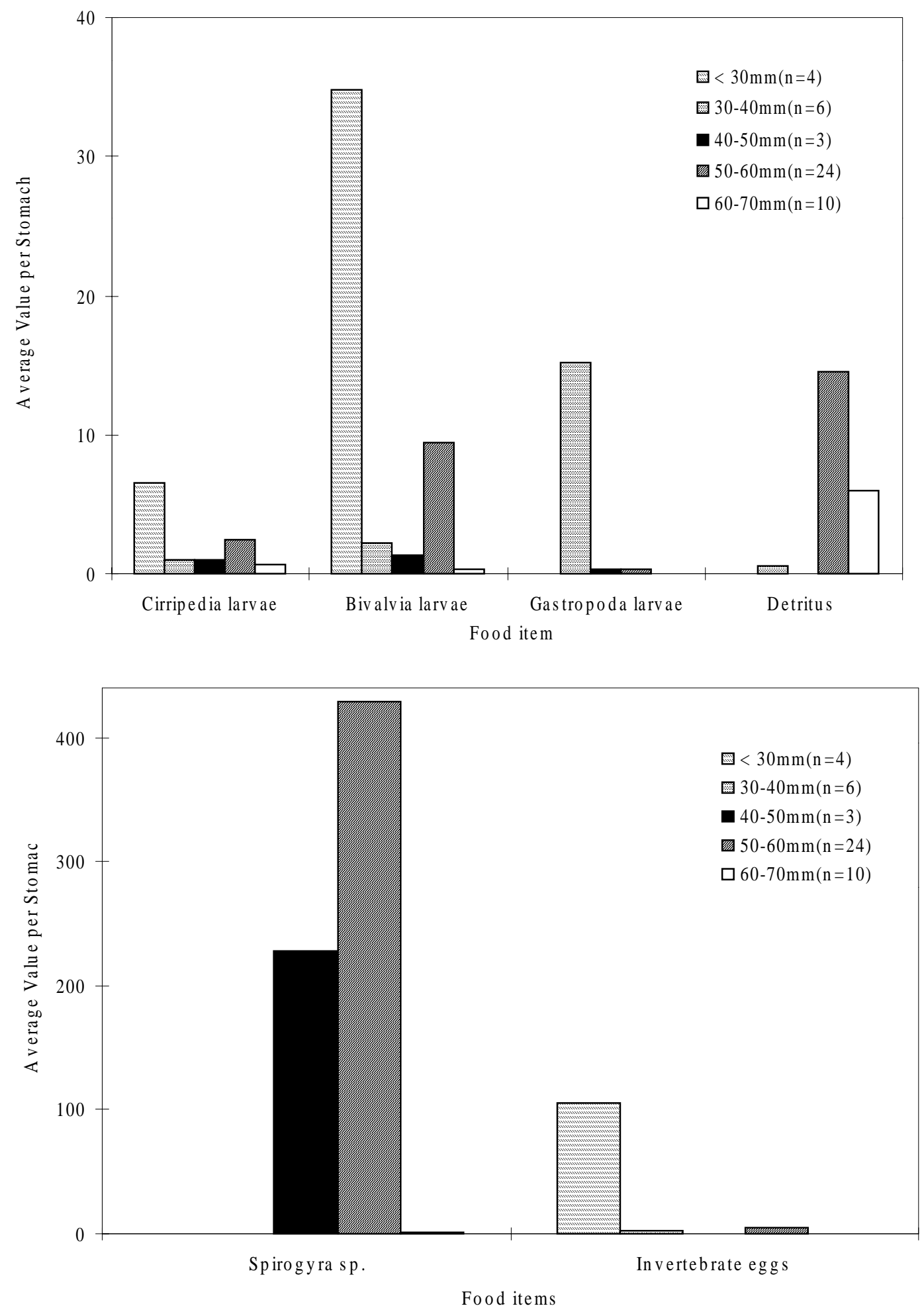

Figure 3 - Average number of important food items ingested by different size classes of Platanichthys. platana collected in Imboassica lagoon (Rio de Janeiro, Brazil). 


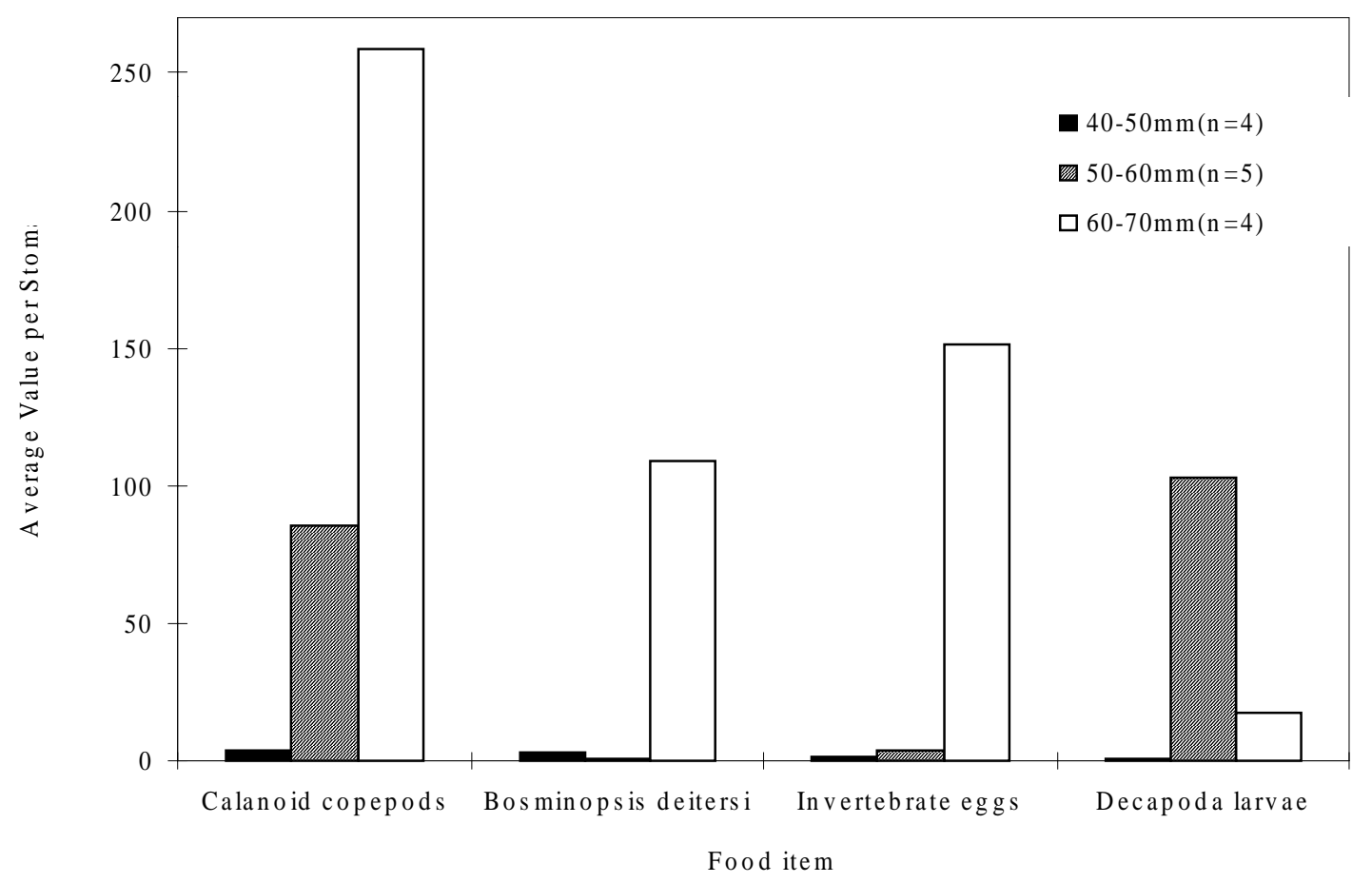

Figure 4 - Average number of important food items ingested by different size classes of Platanichthys platana collected in Cabiúnas lagoon (Rio de Janeiro, Brazil).

\section{ACKNOWLEDGEMENTS}

We would like to thank all the staff of the NUPEM (Núcleo de Pesquisas Ecológicas de Macaé) for their help with this study. This work was supported by CAPES Fellowship.

\section{RESUMO}

Platanichthys platana é uma das espécies constantes nas lagoas costeiras Cabiúnas e Imboassica, as quais se caracterizam por diferentes intensidades de contatos com o mar e por distintos graus de influência antropogênica. A análise dos conteúdos estomacais de exemplares de P. platana capturados entre Julho de 1991 e Julho de 1993 revelou como itens alimentares preferenciais, na lagoa Imboassica, as algas filamentosas, detrito, ovos de organismos bentônicos, larvas de quironomídeos e de bivalves. Cladóceros de pequeno porte, copépodos e larvas de camarão foram os itens predominantes na dieta dos espécimes da lagoa Cabiúnas. Variações sazonais na dieta foram observadas para os peixes da lagoa Imboassica. Diferenças nas dietas dos espécimes com menos de $40 \mathrm{~mm}$ de comprimento padrão foram observadas para a lagoa Imboassica e atribuídas a maior influência marinha resultante das aberturas artificiais da barra de areia. Para os espécimes da lagoa Cabiúnas, foram notadas diferenças no consumo de larvas de invertebrados entre as classes de comprimento.

\section{REFERENCES}

Aguiaro, T. (1994), Fish community structure of three coastal lagoons in Macaé, Rio de Janeiro, Brazil. MSc. Thesis, Universidade do Estado do Rio de Janeiro, 122 pp. [In Portuguese].

Aguiaro, T. (1999), Food spectrum, preferential diet and trophic interactions of fish species in coastal lagoons in the northern coast of Rio de Janeiro State, Brazil. Doctorate Thesis, Universidade Federal de São Carlos, 186 pp. (In Portuguese).

Aguiaro, T. and Caramaschi, E. P. (1995), Ichthyofauna composition of three coastal lagoons in the north of the State of Rio de Janeiro (Brazil). Arquivos de Biologia e Tecnologia, 38, 1181-1189. 
Aguiaro, T. and Caramaschi, E. P. (1998), Trophic guilds in fish assemblages in three coastal lagoons of Rio de Janeiro State (Brazil). Verhandlungen International Vereinigung Limnologie, 26 : (5), 2166-2169.

Albertoni, E. F. (1998), Ocorrência de camarões Peneídeos e Paleomonídeos nas lagoas Imboassica, Cabiúnas, Comprida e Carapebus. In: Esteves, F. A. (ed.). Ecologia das lagoas costeiras do Parque Nacional da Restinga de Jurubatiba e do Município de Macaé (RJ). Rio de Janeiro : NUPEM/UFRJ. pp. 351-358.

Branco, C. W. C. (1998), Composição e aspectos ecológicos das comunidades zooplanctônicas nas lagoas Imboassica, Cabiúnas e Comprida. In: Esteves, F. A. (ed.). Ecologia das lagoas costeiras do Parque Nacional da Restinga de Jurubatiba e do Município de Macaé (RJ). Rio de Janeiro : NUPEM/UFRJ. pp. 247-271.

Branco, C. W. C.; Aguiaro, T.; Esteves, F. A. and Caramaschi, E. P. (1997), Food sources of the teleost Eucinostomus argenteus in two coastal lagoons of Brazil. Studies in Neotropical Fauna and Environment 32, 33-40.

Castillo-Rivera, M.; Kobelkowsky, A. and Zamoya, V. (1996), Food resource partitioning and trophic morphology of Brevoortia gunteri and B. patronus. Journal of Fish Biology, 49, 1102-1111.

Esteves, F.A. (1998), Lagoas costeiras: origem, funcionamento e possibilidades de manejo. In: Esteves, F. A. (ed.). Ecologia das lagoas costeiras do Parque Nacional da Restinga de Jurubatiba e do Município de Macaé (RJ). Rio de Janeiro : NUPEM/UFRJ. pp. 63-87.

Fernandes, V. O. (1998), Variação temporal e espacial na composição da comunidade perifítica na lagoa Imboassica. In: Esteves, F. A. (ed.). Ecologia das lagoas costeiras do Parque Nacional da Restinga de Jurubatiba e do Município de Macaé (RJ). Rio de Janeiro : NUPEM/UFRJ. pp. 221-236.

Gonçalves Jr., J. F.; Fonseca, J. J. L. and Callisto, M. F. P. (1998), Population dynamic of Heleobia australis (Gastropoda) in a coastal lagoon (Rio de Janeiro, Brazil). Verhandlungen International Vereinigung Limnologie, 26, 2056-2057.

Hyslop, E. J. (1980), Stomach content analysis - a review of methods and their application. Journal of Fish Biology, 17, 411-429.

Kornijów, R. (1997), The impact of predation by perch on the size-structure of Chironomus larvae - the role of vertical distribution of the prey in the bottom sediments, and habitat complexity. Hydrobiologia, 342/343, 207-213.

Lazarro, X. (1987), A review of planktivorous fishes: their evolution, feeding behaviour, selectivities and impacts. Hydrobiologia, 146, 97-167.
Melo, S. and Suzuki, M. S. (1998), Variações temporais e espaciais do fitoplâncton das lagoas Imboassica, Cabiúnas e Comprida. In: Esteves, F. A. (ed.). Ecologia das lagoas costeiras do Parque Nacional da Restinga de Jurubatiba e do Município de Macaé $(R J)$. Rio de Janeiro : NUPEM/UFRJ. pp. 177-203.

Pinkas, L. (1971), Food habits study. California Fish Game, Fisheries Bullettin, 152, 5-10.

Zander, C. C. and Berg, J. (1984), Feeding ecology of littoral Gobiid and Blennioid fishes of the Banyuls area (Mediterranean Sea). II. Prey selection and size preference. Vie et Millieu, 34, 149-157.

Received: September 05, 2000; Revised: March 26, 2001; Accepted: October 17, 2002. 